\title{
Racial Myths and the Civil Rights-Era Ku Klux Klan ${ }^{1}$
}

\section{Niko Heikkilä}

University of Turku

\begin{abstract}
In the civil rights-era, the Ku Klux Klan mobilized for the third time. To maintain white supremacy in the U.S. South, violence and terror were among its main tools. The movement's notoriety was buttressed by racial myths and racist stereotypes that drew from wide-ranging sources. The Klan utilized this tradition based on myths, to counter the Civil Rights Movement's successes that had created a sense of urgency and need for action among Klan members and supporters. This article aims to clarify key aspects of certain salient racial myths in the U.S. and examine them within the history of the civil rights-era Ku Klux Klan. On the one hand, the Klan displayed many mainstream positions, of which its fervent anti-communism was a clear example. On the other, by racializing even popular sentiments like anti-communism, the Klan sought to take its ideology beyond politics through its own set of narratives of race, religion, and the nation.
\end{abstract}

Keywords: Ku Klux Klan, race, racism, myth, civil rights era

\section{Introduction}

At a United Klans of America (UKA) rally in October 1961, the Imperial Wizard Robert Shelton delivered a speech in which he referred to his organization as a "new, modern jet-age klan."2 But Klan ideals, Shelton

1 An earlier version of this text was awarded the Orm Øverland Prize 2019. I wish to thank the NAAS Board. My thanks to the two anonymous reviewers for their useful comments and recommendations. I am also grateful to Hannu Salmi, Benita Heiskanen, Kimi Kärki, and Daniel Cobb for their comments and support in writing this article.

2 Cited in U.S. House of Representatives, Committee on Un-American Activities, The Present Day Ku Klux Klan Movement (Washington, D.C.: US Government Printing Office, 1967), 81. 
assured his audience, "have not changed one bit since 1867." The enemies of white supremacy, the "scalawags of today," were a "Communist-directed combination of Negroes and Jews," as he put it. ${ }^{3}$ To take back the country "from alien thieves and traitors," Shelton made "an open declaration of war against the evils of Negroism and Jewism and the Jewish Communists." This allusion to the threat of losing a social order based on white supremacy was an example of many similar reactions that found the most extreme outlet in the mobilization of the Ku Klux Klan. Indeed, Shelton's statement contained three basic components that this article seeks to expand and analyze. I will first explore the myths of white supremacy that contained both religious and political narratives. These are examined in relation to meanings given to crucial events, such as the Mississippi Freedom Summer of 1964 and the civil rights laws that cracked Southern segregation. Second, I will examine myths of the "other" by focusing on how the Klan used salient racial stereotypes in the context of the civil rights struggles. Third, I will analyze how the Klan's self-mythologizing efforts served as inspiration for both militant and social action. While the Klan's racism was direct, in some notable instances, it overlapped with more mainstream racial discourses and myths.

The Ku Klux Klan in its third significant mobilization during the civil rights era embodied the most violent form of resistance against civil rights for black Americans. Pro-segregationists first coalesced around White Citizens' Councils that used economic pressure as their main tool of pressure. At the height of the civil rights struggles in 1964-65, the Klan came to symbolize "last-ditch" resistance and resorted to much more radical means. In early 1967, the Klan movement consisted of 15 independent organizations whose total estimated membership was approximately 16,810 members. ${ }^{5}$

\footnotetext{
Ibid.

Ibid., 81-82.

On White Citizens' Councils. see for example "The Citizens' Council: A History," in Michael Edmonds, ed. by, Risking Everything: A Freedom Summer Reader (Madison: Wisconsin Historical Society Press, 2014), 80-85. The membership figures come from the House Un-American Committee report. See U.S. House of Representatives, The Present Day Ku Klux Klan Movement, 17-20, 62. During Klan resurgence in the early 1960 s, the ADL estimated that in addition to "hardcore" Klan membership of around 10,000, there were an additional 25,000 to 35,000 "likeminded racists" in Klan-type groups. See Arnold Forster and Benjamin R. Epstein, Report on the Ku Klux Klan (New York: Anti-Defamation League of B'nai B'rith, 1965), 6-7. Other studies have estimated Klan membership in the civil rights-era to be as high as 55,000. See for example Andrew Selepak \& John Sutherland, "The Ku Klux Klan, Conservative Politics and Religion: Taking Extremism to the Political Mainstream," Politics, Religion \& Ideology 13, 1 (2012): 80.
} 
The civil rights-era thus witnessed the third significant Klan mobilization, which relied on similar means and passions that energized people behind this white supremacist cause previously. Each Klan mobilization occurred at a time when whites saw their status and power threatened. The Klan first emerged out of the ruins of the Civil War that ended slavery. Second mobilization occurred in the 1920s that witnessed a rise in the number of immigrants from Southern and Eastern Europe. In the 1920s, the Klan was also a national phenomenon and had support across the country. AntiCatholicism and anti-Semitism were introduced to and formed an important feature of Klan ideology in 1920s. Again, a crisis mood formed when the Civil Rights Movement had effectively organized to end segregation, and those who joined or supported the Klan in the 1960s saw this as a threat to their "way of life."

The nearly one-hundred-year history behind the movement provided a tradition to follow and imitate, while the successes of the Civil Rights Movement highlighted the urgency and need for action among Klan members and supporters. However, unlike in the 1920s, the civil rights-era Klan was mostly a Southern movement and issues like anti-Catholicism were much less important. At the same time, anti-Semitism remained to be evoked especially in connection to anti-communism and conspiracy theories in which Jewish influence was seen to play a role in subversive activities in general and the Civil Rights Movement specifically. Overall, established traditions and myths had a prominent place in the Klan's ideological narratives and depictions of perceived enemies. ${ }^{7}$ On one hand, the Klan displayed many mainstream positions, of which its fervent anticommunism was a clear example. On the other, by racializing even popular sentiments like anti-communism, the Klan sought to take its ideology beyond politics through myths of race, religion, and the nation.

Despite the air of power and strength the Klan aimed to project, such white supremacist movements are typically reactive and can rise and fall in a brief period of time. ${ }^{8}$ Myths and stereotypes are, by contrast, much more deeply

6 Rory McVeigh and Kevin Estep, The Politics of Losing: Trump, the Klan, and the Mainstreaming of Resentment (New York: Columbia University Press, 2019), 1-8, 38-47.

7 Federal Bureau of Investigation, Klan Organizations Section III, 1958 - 1964 (United States Department of Justice, 1964), 4.

8 FBI, Klan Organizations, 3. On reactive mobilization, see David Cunningham, Klansville, U.S.A.: The Rise and Fall of the Civil Rights-Era Ku Klux Klan (Oxford \& New York: Oxford University Press, 2013), 7-10. 
rooted in various aspects of racial discourse. Following Christopher Flood, who uses the concept of political myth, I refer to myth as "an ideologically marked narrative which purports to give a true account of a set of past, present, or predicted political events and which is accepted as valid in its essentials by a social group." As Flood points out, political myth relates to but is distinct from both sacred myths and ideology. In the case of the Klan, however, these distinctions overlap in certain aspects, specifically in terms of the role of myth in "the maintenance or imposition of hierarchical domination by one group over others." ${ }^{10}$ Additionally, another important dimension relates to the concept of "race" vis-à-vis myths. In this respect, Stuart Hall and Roland Barthes have provided a valuable approach with which to explore this contested terrain:

Myth hides nothing and flaunts nothing: it distorts; myth is neither a lie nor a confession; it is an inflection...[D]riven to having either to unveil or to liquidate the concept, it will naturalize it. We reach here the very principle of myth: it transforms history into nature... $[\mathrm{M}] \mathrm{yth}$ is speech justified in excess. ${ }^{11}$

Myth thus, by transforming history into nature, can function as a way to create a purified and romanticized understanding of the past, providing a useful tool in the agenda of different people and groups. As Hall observed, such an approach also sheds light on why discredited notions like scientific definitions and biological understandings of race are "unlikely to disappear entirely from discourses of racial difference."12

Racial myths, such as those evoked by the Klan, were made to appear as if they were natural and essential - that is, detached from history, to explain contemporary conditions and to provide justifications for a particular agenda. But this is precisely why "race" needs to be examined historically as a "complex of social meanings constantly being transformed by political struggle." For as Omi and Winant write, "racial signification is always and necessarily a social and historical process." ${ }^{13}$ Like the notion of

9 Christopher G. Flood, Political Myth: A Theoretical Introduction (New York and London: Garland Publishing, Inc., 1996), 44.

10 Ibid., 41.

11 Barthes cited in Stuart Hall, The Fateful Triangle: Race, Ethnicity, Nation (Cambridge, MA: Harvard University Press, 2017), 59.

12 Ibid., 59-60.

13 Michael Omi and Howard Winant, Racial Formation in the United States: From the 1960s to the 1990s (New York and London: Routledge, 1994), 55. 
"race," myths, too, are understood from the present and amenable to change according to a given historical place, time, and conditions. Additionally, George Fredrickson's definition of racism helps to understand white supremacy in the civil rights-era. Fredrickson noted that beyond attitudes or beliefs, racism "expresses itself in the practices, institutions, and structures that a sense of deep difference justifies or validates." 14 Systemic view of racism takes into account how the Klan both exploited attitudes and beliefs based on prejudices and worked to defend the institutions and practices of white supremacy.

As sources, I have used Klan publications such as The Fiery Cross magazine, published monthly by the United Klans of America for Klansmen and supporters. I have used issues published between the years 1969 and 1970. Another important source has been the House Un-American Committee report that reprinted numerous Klan texts and was published in 1967. Reprinted material was originally published between 1960 and 1966 and conveys aspects of organizing like Klan ideals, principles, and values. I have also used investigative reports compiled by the FBI and watchdog groups such as the Anti-Defamation League, as well as newspaper articles. Final category of sources consists of propagandistic material like narrated records of Wallace "Wally" Butterworth who at some point in the early 1960s worked with both the UKA and the National Knights of the Ku Klux Klan. Butterworth's records reveal attempts to recruit and spread Klan message to larger audiences in the early and mid-1960s. In practice, these sources are analyzed by identifying pertinent myths of white supremacy and of the "other," followed by a contextualization of how Klan used these narratives in elevating whiteness and denigrating the other. Ultimately, such a task can offer some additional insight into the "stubborn endurance of "race" as a marker of essential biological differences," as Henry Louis Gates, Jr. put it. ${ }^{15}$

\section{The Myth of White Supremacy in Klan Ideology}

Dated May 3, 1964, an Imperial Executive Order of the White Knights of the Ku Klux Klan issued a stark warning to its members: "The military and political situation as regards the enemy has now reached the crisis

14 George Fredrickson, Racism: A Brief History (Princeton: Princeton University Press, 2015), 6.

15 Henry Louis Gates, Jr., "Foreword," in The Fateful Triangle, x. 
stage." ${ }^{16}$ The White Knights, based in Mississippi, were an independent Klan organization, identified by law enforcement and observers as one of the most secretive, militant, and violent group active at the time. ${ }^{17}$ The "crisis stage" mentioned in the order was the upcoming Mississippi Freedom Summer. That momentous organizing effort by the Civil Rights Movement in the summer of 1964 is now remembered as a pivotal moment in civil rights history. Even those opposing every effort to desegregate the South deemed the Freedom Summer as a significant event with meaningful ramifications. In some formulations, the Freedom Summer was elevated into nearly mythical proportions. For example, the Mississippi White Knights reasoned: "Our best students of enemy strategy and technique are in almost complete agreement that the events which will occur in Mississippi this summer may well determine the fate of Christian Civilization for centuries to come." ${ }^{18}$ Framed as a tectonic moment, the responsibility of defending "Christian Civilization" was placed on the shoulders of the White Knights as the first and last line of defense.

Seemingly, these extravagant claims were used to build an appropriate response: for in this particular outlook, not only the nation but the entire "Christian Civilization" was under threat. Extraordinary times required extraordinary response, as militancy and Christianity came together in preparation for the "coming battle." For example, the pairing of religious zeal with military fervor was captured in battle cries like this: "[T]he situation calls for the highest degree of combined intelligence and courage combined with a sincere, Christian Devotion, which Christian Soldiers have ever been called to demonstrate." ${ }^{19}$ It was religion evoked to highlight the urgency of a battle that was fought on an institutional level as well as in the streets of Mississippi. In Christian terms, this might be understood as a particular white supremacist idea of a "calling."

Using the guise of Christianity, the Klan built its own myths from various sources including selective Bible passages. To fulfill what Nancy MacLean has called as the need of faith and symbolism, the Klan even had its own form of ceremonies and practices known as "Klankraft." ${ }^{20}$ Additionally,

16 “Imperial Executive Order," in The Present Day Ku Klux Klan Movement, 169.

17 Forster and Epstein, Report on the Ku Klux Klan, 10-11.

18 "Imperial Executive Order," in The Present Day Ku Klux Klan Movement, 169.

19 Ibid.

20 Nancy K. MacLean, Behind the Mask of Chivalry: The Making of the Second Ku Klux Klan (New York: Oxford University Press, 1994), 93. 
Klan rallies featured strong religious, ceremonial, and ritualistic elements while notions like "sublime" and "sanctified" were often referenced in Klan writings about Christianity. ${ }^{21}$ But the Klan had also transformed the most sacred symbol of Christianity, the Christian cross, into that notorious symbol of white supremacy and terror, the fiery cross. In this capacity, such forms of self-mythologizing also functioned to maintain the hierarchies of structured difference by means of terror if needed.

Because numerous Klan organizations declared their aims and principles in clear words that their purpose was "the maintenance of white supremacy," racial hierarchies were seen as a "natural" way to organize society. Ordained by God, this view was articulated as a primary aim to "maintain forever segregation of the races and the divinely directed and historically proven supremacy of the white race," emphasizing "strict segregation of the races, and the control of the social structure in the hands of the Christian, Anglo-Saxon white men."22 Along with the myth of Anglo-Saxon superiority, the White Knights also highlighted "Christian Civilization" as an organizing principle: "The purpose and function of this organization is to preserve Christian Civilization," read a White Knights executive lecture. ${ }^{23}$ Indeed, the Klan consistently evoked Christianity as a point of reference, declaring Christian ideals as the order's highest principle. But theology was not a matter of debate, it was a means to sanctify racist myths and the "supremacy of the white race" to support contemporary political and social projects. This was expressed in terms like "God drew the color line" or "God is the author of segregation," often accompanied by a reference to the separation of Cain and Abel or specific verses that supposedly justified racial difference. ${ }^{24}$ Segregationist theology along with white supremacy, anti-communism, and nativism were the key components of Klan ideology of Christian Americanism. ${ }^{25}$

In most cases, references to Christianity meant specifically Protestant Christianity. For example, the Original Ku Klux Klan of Louisiana limited membership to "Mature, Native-born, White, Gentile Men." Profession

21 "The Seven Symbols of the Klan," in The Present Day Ku Klux Klan Movement, 349; Cunningham, Klansville, U.S.A., 43-51.

22 Cited in U.S. House of Representatives, The Present Day Ku Klux Klan Movement, 75.

23 "Executive Lecture of March 1, 1964," in The Present Day Ku Klux Klan Movement, 164.

24 See for example, "The Principle of the United Klans of America Knights of the Ku Klux Klan," in The Present Day Ku Klux Klan Movement, 366.

25 John Drabble, "From White Supremacy to White Power: The FBI, COINTELPRO-WHITE HATE, and the Nazification of the Klan in the 1970s," American Studies 48, 3 (Fall 2007): 49-50. 
and practice of the Christian Faith was another requirement, but members of the Roman Catholic Church were not admitted to the organization. ${ }^{26}$ However, anti-Catholicism was not as relevant as it had been in the 1920s, although anti-Catholicism could be occasionally evoked at Klan platforms in the 1960s. Then again, mostly Catholic cities like St. Augustine, Florida, witnessed high levels of Klan mobilization because communism and the Civil Rights Movement were seen to form a much more salient threat. ${ }^{27}$ These ambiguities were also represented in the politics of whiteness. In a broader view, as Nell Irvin Painter pointed out, the "fourth enlargement of American whiteness" meant that "races of Europe" discourse was no longer part of the mainstream understanding by the 1960s. Yet it was only a generation earlier that Italians and Jews as an example were labeled as "races." 28

Cultural arguments and theological reasons for racial hierarchies extended to political matters. Drawing from a lengthy and abundant tradition of myths of "superior" and "inferior" races, the Klan of the 1960s relied heavily on older nativist and white supremacist beliefs about political institutions in the U.S. For example, to the Know-Nothing leader Daniel Ullman, the "genius of American constitution" could be deduced from four racial elements of Britain: "The chief element was undoubtedly Germanic. Hence springs the inherent love of freedom of the Anglo-Saxons in England and America, which had been the hereditary characteristic of the Teutonic or Germanic race from the earliest period. ${ }^{29}$ In similar terms, by attributing the Constitution and relating republican ideals to the "genius of AngloSaxon race," the Klan understood the "origins" and "sources" of the nation in specific racial terms. As Matthew Frye Jacobson observes, however, "the ever-present threat of decline" was a constant political danger facing "racial greatness." 30 Threats to "racial greatness" and the nation have changed so that each period had its own set of primary targets. During the civil rights era, the Klan understood whiteness through authenticity. David Cunningham

26 "The Konstitution of the Original Ku Klux Klan Realm of Louisiana," in The Present Day Ku Klux Klan Movement, 300.

27 David M. Chalmers, Hooded Americanism: The History of the Ku Klux Klan (New York: Franklin Watts, 1981), 377.

28 Nell Irvin Painter, The History of White People (New York: W. W. Norton \& Company, Inc., 2010), 383.

29 Cited in Matthew Frye Jacobson, Whiteness of a Different Color: European Immigrants and the Alchemy of Race (Cambridge, Mass.: Harvard University Press, 1999), 71.

30 Ibid. 
has argued that a Klan view of whiteness was linked to beliefs. To be "authentically white" was to support segregation. Those who did not were deemed as "white niggers" who had abandoned racial purity. ${ }^{31}$ Markers of difference were vital to racially and politically motivated mythologizing.

In using history as inspiration, one of the most effective propaganda weapons for the Klan has been The Birth of a Nation (1915). It contributed enormously to broader myths of the Klan and reinforced stereotypes of the "other." The motion picture enjoyed an enthusiastic reception by audiences across the country. Moreover, the famous quote "like writing history with a lightning" attributed to President Woodrow Wilson added yet another layer into the myths, though some have since questioned the accuracy of the quote..$^{32}$ The popularity of the film in 1915 and the appeal of the second Klan in the 1920s was not an anomaly. For during the first three decades of the twentieth century, racialist thought reached its peak, enjoying a broad appeal in history, science, social science, and popular culture.$^{33}$ But the film itself relates to the history of the South after it lost the Civil War. While slavery ended, the subordination of black people continued. As James Cone has noted, the image of black men and women transformed from "Sambos" to "black beast rapists" and from "Mammies" to "Jezebels" in the white imagination. ${ }^{34}$ These narratives were an explicit part of the Birth of a Nation and served to buttress a social order that was depicted as transitions from order to chaos, from chaos to order, with a "dark nightmare at the center of this disaster fantasy." 35 The Klan, in turn, was depicted as the heroic savior of the South. On the Birth of a Nation, James Snead wrote, "In unprecedented ways, film form and racism coalesce into myth here, seemingly myths of entertainment but ultimately ones political in nature, ones that continue to assert their presence today." ${ }^{36}$ The film popularized racist stereotypes and built Klan lore in national consciousness better than

31 Cunningham, Klansville, U.S.A., 141.

32 On Birth of a Nation and black images, see for example James Snead, White Screens, Black Images: Hollywood from the Dark Side, ed. by Colin MacCabe \& Cornel West (New York: Routledge, 1994), 37-45. On the validity of Wilson's quote, see Mark E. Benbow, "Birth of a Quotation: Woodrow Wilson and "Like Writing History with Lightning,"” The Journal of the Gilded Age and Progressive Era 9, 4 (October 2010): 509-533.

33 MacLean, Behind the Mask of Chivalry, 133.

34 James H. Cone, The Cross and the Lynching Tree (New York: Orbis Books, 2013), 6.

35 Ibid., 39.

36 Snead, White Screens, Black Images, 38-39. 
any other propaganda campaigns and better than anything the Klan itself produced.$^{37}$ These myths, moral notions, and values were united in the film and can be taken as ideological justifications for white supremacy used by subsequent Klan waves.

As the central ideological message of film was that only after the black man was "put into his place" and notions of equality were squashed could the nation be born again. In the 1960s, the Klan wanted to reenact that story. Just as Griffith's film reproduced "nostalgia" as "history," so the Klan used various myths as building blocks to promote its race-based ideology. ${ }^{38}$ During the resurgence of the civil rights era, the Klan used the myth of Klan "heroism" to promote Anglo-Saxon superiority and to attack its enemies.

\section{Racist Stereotypes and Enemy Imagery in the Klan's Paranoid Style}

Although the Klan and similar groups held biological and essential beliefs of "race," their interest in scientific racism or more intellectual attempts to justify racial hierarchies was almost nonexistent. Instead, emotive appeals based on narratives and myths buttressed the Klan's propaganda of the other. In the most obvious and racist form, the Klan used and reproduced the narratives of "black beasts" in the context of "race riots" that started in Harlem in 1964, gripping many major cities between 1964 and 1968. Before examining the Klan's reaction, a couple of mainstream examples help to underscore certain shifts in race politics. For in the mainstream, explanations and reactions to the riots were more wide ranging. From the Second World War to the 1960s, for obvious reasons, racial discourse went through a profound transformation. It was not only the experience of fascism and the holocaust but developments in science that led Western countries to reconsider theories about "race." As Kenan Malik has noted, UNESCO-sponsored meetings between social scientists and biologists led to the conclusion that rather than a biological phenomenon, "race" was a "social myth" and had caused "an enormous amount of human and social damage." ${ }^{39}$ While the promotion of biological racial ideas was in the political

39 The United Nations especially promoted the ideas of racial equality at the heart of its project. Also, the gatherings social scientists and biologists were sponsored by UNESCO, "to disprove the claims of racial science.” These meetings occurred on four occasions (1949, 1951, 1964, and 1967). Kenan Malik, The 
and scientific margins, social scientific emphasis on and understandings of racial problems were part of the mainstream U.S. discourse. However, this reorientation was not without its problems.

Daniel Moynihan's famous study in the mid-1960s, for example, identified "ghetto culture" as the main reason for large numbers of singlemother families in the black community. The behavior, Moynihan argued, constituted a social pathology and was dominated by pathological cultural values, "a tangle of pathology." ${ }^{40}$ Moynihan's thesis was echoed by other mainstream commentators like Theodore White whose interpretation placed riots at the center of a racial awakening that was not a sectional concern but a nationwide phenomenon. White predicted, or more precisely saw as a "gross fact," "that the great cities of America are becoming Negro cities." As Taylor Branch has pointed out, White added to that prediction that the meaning of the term "backlash" would change as "its reference began to shift toward a pathology among city Negroes" due to the riots. Thus riots, according to White, were "not only physical terror in those streets where the decent are the prey of the savages, but an intellectual terror which condemns as Uncle Toms or traitors all who try to participate in the general community or lead the way to better life." 42

Such social pathology explanations, articulated by liberals and conservatives, can be found in a less subtle and less intellectual form in the open racism of the Klan. The combination of this "tangle of pathology," coupled with essentialism and recurring racial myths, underscored some of the more explosive articulations put forward by the Klan. As extreme expressions of the white backlash mood, they were closely connected to the ensuing discourses and politics of "law and order." Wally Butterworth provides a clear example of a fiery rhetoric that served as an emotive stimulus for a Klan-style backlash.

In one of his records, Butterworth lamented the Civil Rights bill as "America's funeral service," provoking the dual specter of "traitorous

Meaning of Race: Race, History and Culture in Western Society (Basingstoke: MacMillan, 1996), 15.

40 Official title of the "Moynihan Report," was The Negro Family: A Case for National Action, published in 1965. For analysis on the legacy of the report, see for example Daniel Geary, Beyond Civil Rights: The Moynihan Report and Its Legacy (Philadelphia, Pa.: University of Pennsylvania Press, 2015).

41 Cited in Taylor Branch, Pillar of Fire: America in the King Years, 1963-65 (New York: Simon \& Schuster, 1998), 419.

42 Cited in Branch, Pillar of Fire, 419. 
government" and "communist-trained Negroes" in the streets. ${ }^{43}$ The bill was, according to Butterworth, "an open admission that Jew-Communism rules in America." Any force taken against civil rights was permissible, he added, and proceeded to detail how Jews have been behind "every communist law" in "this formerly free republic." Butterworth also urged white Americans to arm their "homes against communist-led Negro riots." Ironically, he claimed that civil rights marches against segregation were "law-breaking" and promoted "race-hatred between Americans." ${ }^{44} \mathrm{He}$ evoked deep racist tropes of black people ranging from "Negro crime and disease in the United States" to the role of race in a "plan for world government led by LBJ." ${ }^{45}$

What Butterworth referred to as "Negro crime and disease" was a deliberate attempt to fuse dehumanizing and cultural arguments with biological and pathological terms. Hierarchical and imagined racial order rested on specific justifications and myths of different groups. In this power hierarchy, the symbol of social ills was most often the black man, illustrated in frequent metaphors and associations with "disease," "perversion," "crime," "apes," "beasts," and so on. Jewish people, in turn, were depicted as the main political enemies, for the "Jew," according to Klan conspiracy, was behind communism, socialism, controlled the news, were the architects of civil rights, and so on. Though the narrative might have been coherent and palatable to Klansmen, it was still conflicted. Anti-Semitism, much like other racist elements, provided a common denominator for conflicting claims. For example, Klansmen could claim that Jews were simultaneously finance capitalists and communists. When historical narratives and old beliefs were rendered to serve new political and social ends in the context of civil rights, they were often articulated as conspiracies. And as such, they were part of what Richard Hofstadter termed as the "paranoid style in American politics." ${ }^{46}$

"The central image is that of a vast and sinister conspiracy," Hofstadter wrote on the basic elements in the paranoid style, "a gigantic and yet subtle

43 Wally Butterworth, "Civil Rights America's Funeral Service," available at https://archive.org/details/ TheWallyButterworthCollection/CivilRightsAmericasFuneralService.mp3 (accessed July 30, 2019).

44 Wally Butterworth, "Guns to Arm Your Homes Against Communist-led Negro Riots," available at https:// archive.org/details/TheWallyButterworthCollection/CivilRightsAmericasFuneral Service.mp3 (accessed July 30, 2019).

45 Ibid.

46 Richard Hofstadter, "The Paranoid Style in American Politics," in The Paranoid Style in American Politics and Other Essays (New York: Alfred A. Knopf, 1966). 
machinery of influence set in motion to undermine and destroy a way of life." ${ }^{47}$ The Klan's contribution to the paranoid style was to center the conspiracy on racial difference. In Klan outlook, most often the belief in white supremacy was the overriding concern and primary motive. From this tendency to give a racial explanation to current affairs and history, a conspiracy was a means to reveal and relate to other social concerns, such as anxieties of communist subversion and the breakdown of law and order. Another key building bloc of the conspiracy also drew from Christianity, using history and myths to frame contemporary political narratives. For example, in an anti-Semitic polemic produced by WASP, Inc., the long tradition of anti-Semitism was used to reveal the contemporary conspiracy as specifically Jewish-led. The article first claimed that Jews were responsible for the crucifixion of Christ, and then saw similarities between the Temple business and the "modern, world-wide, international cartel which uses the name "Jew."" 48 Borrowing from religious rhetoric, Klan often personalized notions of "Demon" and "Satan" - implicitly or explicitly - in the concrete form of the "Jew," with recurring references to "the synagogue of Satan." These forces of "Satan" were also depicted as champions of "negative, materialistic force of destruction," possessing "supernatural" power that was the embodiment of "evil" and "malign."

Typically, anxieties were personalized and formulated as concrete warnings like this: "If we don't win in the next eight months, we're all destined for Communist slavery and our wives and daughters will be chattels in Mongolian and African brothels." ${ }^{50}$ A Fiery Cross article entitled "The Death of a Nation" gives another take on the motives and means behind the conspiracy. By taking over or infiltrating important institutions like higher education, the media, the Federal government, the Church, and so on, communists were aiming to destroy the morals of the nation and to control currency and finance. This was but a one version of the sinister plot that stalked the land.$^{51}$ It was also a racial and spiritual struggle, expressed in explicit terms. In another article, "God \& Country v. the New Order," the National Council of Churches was termed as an "umbrella group for

47 Hofstadter, "The Paranoid Style in American Politics," 29.

48 "WASP, Inc. (A Christian Non-Profit Organization Dedicated to the Christian American Heritage)," February 1, 1968, in The Present Day Ku Klux Klan Movement, 293.

49 "Executive Lecture of March 1, 1964," in The Present Day Ku Klux Klan Movement, 164. See also Hofstadter "The Paranoid Style in American Politics," 31-32.

50 Cited in Forster and Epstein, Report on the Ku Klux Klan, 12.

51 "The Death of a Nation," The Fiery Cross (June 1970), 34-35. 
Communist agitators." ${ }^{52}$ The National Council of Churches, according to the article, was assisting the "communist conspirators" in correcting "the mistake they appear to believe GOD made when He created the separate and distinct races." Their plan was, then, one of forced race mixing, the article claimed. Such umbrella groups were used by communists to trap the "unsuspecting and gullible" to finance plans for "World Revolution." Part of this revolution was what the Klan referred to as "communist inspired Black Revolution" that required special attention..$^{53}$

The notion and movement of Black Power was one of the most important developments that followed the Civil Act of 1964 and the Voting Rights Act of 1965. New civil rights laws alone deepened the pessimism among Klan constituents, while the latter half of the 1960s simultaneously produced more militant responses to racial hatred on the part of the black community, as David Cunningham observes ${ }^{54}$ These social realities came to be increasingly understood by the Klan as a conspiracy fixated on the breakdown of racial order. Mainstream ideological positions like anticommunism and law and order intertwined in Klan conspiracy with racist myths. Riots in many major U.S. cities between 1964 and 1968, along with the emergence of Black Power, led the Klan to believe that there was a "nationwide conspiracy of sabotage, arson, and guerilla warfare" raging across the country. ${ }^{55}$ Rioting and the rise of Black Power were interpreted either as part of a broader communist conspiracy or a complete breakdown of law and order. The latter position had firm links to racial fears and myths about African Americans. And as a recruiting tool and mobilizing passion, denigrating African Americans was always followed by the largest applause, providing "the most bang for the UKA's buck," as Cunningham put it. ${ }^{56}$

In early 1968, the Klan claimed that "Negro rioting and the advocacy of violence by Black Power militants have helped push Ku Klux Klan membership to the highest peak in two decades." ${ }^{57}$ While there might have been a small boost, in reality the Klan was in decline by this time. Unlike the Klan of the 1920s, the Klan in the 1960s was not a unified movement. There were instead many competing organizations whose internal disputes

52 “God \& Country v. the New Order," The Fiery Cross (August 1969), 8.

53 Ibid.

54 Cunningham, Klansville, U.S.A., 187.

55 "The Beast That Stalks Our Land," The Fiery Cross (August 1969), 17.

56 Cunningham, Klansville, U.S.A., 146.

57 "Ku Klux Klan Leaders Claim Their Rolls Are Boosted by Negro Militancy," The Washington Post (January 18, 1968), C19. 
were further exploited by the FBI through its counterintelligence program (COINTELPRO-White Hate) that was initiated in 1964 to disrupt and neutralize Klan organizations. ${ }^{58}$ These factors, coupled with a broader societal response to Klan violence, contributed to the decline of Klan organizations. HUAC had estimated the total Klan membership to be approximately 16,810 in $1967 . .^{59}$ Membership in Klan organizations kept falling each year, dropping to approximately 4,300 by April $1971 .{ }^{60}$ For example, a shootout between African Americans and Klansmen in North Carolina in 1969 revealed a Klan in trouble. Joe Bryant, a Klan officer, described the incident as one in which he "was leading a rally there when the niggers started trouble and which as decent white people we could not stomach." "It was hell," he added, "our wives and children were out there in the blackness with those niggers while we were in jail." ${ }^{61}$ The shootout contributed to further dissension and feuding inside the North Carolina chapter of the UKA, leading one group to break away. In addition to internal disarray, comments made by Bryant provide an interesting parallel to the myth depicted in The Birth of a Nation. The "blackness" and the "dark nightmare," in a similar narrative as in the film, was threatening white women and children and "decent white people could not stomach" this. While myths provided ready-made narratives for understanding social change, it was obvious that the myth of the Klan as savior of white supremacy in the South during Reconstruction would not be repeated in the civil rights era.

\section{From Enemy Images to Action}

Although "race" was never simply about white and black, this dualism was the most obvious signifier of racial difference for the Klan in the civil rights era. ${ }^{62}$ During this period, the black civil rights struggle was the primary

58 On COINTELPRO, see for example David Cunningham, There's Something Happening Here: The New Left, the Klan, and FBI Counterintelligence (Berkeley: University of California Press, 2004).

59 U.S. House of Representatives, The Present Day Ku Klux Klan Movement, 62.

60 Drabble, "From White Supremacy to White Power," 56. During the 1920s, the Klan had somewhere between 3 and 5 million members at its peak around the mid-1920s. See Cunningham, Klansville, U.S.A., 24-25. To contextualize those numbers, U.S. population in 1920 was approximately 106 million. In 1970, U.S. population was approximately 203 million.

61 “Klan In Trouble In North Carolina: Group Is Split and Bankrupt - 'Real Trouble' Feared,” The New York Times (September 17, 1969), 17.

62 There are many versions of racial hierarchies, of different "European races" within the category of "white." In the context of the U.S., Nell Irvin Painter for example has identified four enlargements of “American whiteness." See Painter, The History of White People. 
driving force behind a sense of crisis felt by white supremacists. As the Civil Rights Movement had set the terms of social change, there were even attempts by Klan-like organizations to imitate these successes. "Let's be nonviolent," some Klan leaders explained, "we've got to start fighting like the niggers." ${ }^{63}$ UKA leader Robert Shelton was a good representative of attempts to recruit members by focusing on patriotism, "benevolence," and nonviolence.$^{64}$ For example, an FBI monograph on Klan activities outlined that "Shelton's efforts have been devoted mainly to changing the image of the Klan from one of violent, fanatical night riders to one of political activists." ${ }^{65}$ This type of imitation of the enemy was, according to Richard Hofstadter, the fundamental paradox of the "paranoid style." ${ }^{66}$ However, public efforts to put forth an image of "benevolence" by Shelton stood in contrast to the White Knights whose leader Sam Bowers referred to his organization "as a kind of military operation." These different public orientations were, however, reflective of more rhetorical than practical realities. ${ }^{67}$

Although it is true that only a relatively few Klan members participated in organized violence, these functions were assigned to special "action groups" that used "strong-arm tactics and violent actions to achieve their aims." David Cunningham has observed that violent action groups did not operate without organizational consent but were often recruited and cultivated by Klan leadership. ${ }^{68}$ In the 1960 s, the Klan used two oppositional tactics. One was to put forth an image of political activism and to emphasize nonviolence in public efforts. The other was to act in secrecy and to use violence to enforce white supremacy. There were also imitations of Civil Rights Movement tactics that included attempts to organize rallies, registration drives, boycotts, and sit-ins. This was presumably part of what Shelton meant by a "new, jet-age klan."

Groups that had better organizational abilities, like the UKA, were more systematic in using public rallies to espouse the cause. A House

63 Chalmers, Hooded Americanism, 373.

64 Cunningham, There's Something Happening Here, 69.

65 FBI, Klan Organizations, 70.

66 Hofstadter, "The Paranoid Style in American Politics," 32. Corey Robin has pointed out that from the French Revolution to black and women's freedom, reactions of the right always move according to changes in the movements of the left. Corey Robin, The Reactionary Mind: Conservatism from Edmund Burke to Sarah Palin (Oxford and New York: Oxford University Press, 2011), 35.

67 “Executive Lecture of March 1, 1964," in The Present Day Ku Klux Klan Movement, 164.

68 Cunningham, There's Something Happening Here, 68. 
investigation committee found that the UKA, by means of public rallies, could attract members from the White Knights, whose involvement in numerous acts of violence and terror was cited as another crucial factor in switches. Conversely, the committee also observed "that a number of violence-prone members of the White Knights had actually gone over to the United Klans on the grounds that the White Knights was not militant enough." ${ }^{\prime 69}$ Whether or not these findings were fully accurate, they still capture the confusion within that mental atmosphere on how to react to social change. Such moments of crisis crystallized the ideology of white supremacy, strengthening connections and providing prescriptions for action. $^{70}$

As an example of mixed responses and messages, public calls to use "ballots and boycotts - not bullets" were issued alongside suggestions to "[s]tock up on rifles and shotguns and pistols, all of standard make, and lots of ammunition." 71 On a political level, the Klan was never able to become a voting bloc as some leaders had envisioned. But the UKA, like most Klan supporters, backed George Wallace's 1968 presidential campaign, contributing paraphernalia and billboards in support of the campaign. David Cunningham, studying the North Carolina UKA, noted that there was a correlation between votes for Wallace and the strength of the UKA in particular counties. These were signals of a broader fracture in which counties that had traditionally supported the Democratic Party shifted toward the Republican Party in 1968 and 1972..$^{72}$

More crucially, it was the "bullets" strategy that the Klan's notoriety was built on. Although not all violence during Freedom Summer was perpetrated by Klansmen, it did not take many men, who could operate in secrecy, to create an atmosphere of terror. During Freedom Summer, the Klan and other hardline segregationists were responsible for numerous bombings, cross-burnings, church attacks, and other acts of terror. However, it was the publicity of the murders of Michael Schwerner, James Chaney, and Andrew Goodman in Mississippi that placed the nation's eyes on Mississippi and Klan violence. Nationally prominent murders, like the three civil rights workers in Mississippi, Lt. Col. Lemuel Penn in Georgia in 1964 and Viola

69 U.S. House of Representatives, The Present Day Ku Klux Klan Movement, 46-47.

70 On myths in general in similar situations, see Flood, Political Myth, 21.

71 Forster and Epstein, Report on the Ku Klux Klan, 12.

72 Cunningham, Klansville, U.S.A., 219-221. 
Liuzzo in Selma in 1965, fueled public anger and increased action on the part of the federal government. ${ }^{73}$

It is perhaps suggestive of broader racial politics of the time that the largest amount of media attention and national outrage was given to the murders of white northerners. Violent action was still only part of the picture. National and Southern reactions to Klan violence reveal some interesting insights about racial myths, for there were still deep-seated societal rifts based on racialized outlook. According to David Chalmers, many respectable people and the power structure in Mississippi, especially in larger cities, worked to prevent rather than advance violence. ${ }^{74}$ While they might have been contemptuous of the Klan, still "a nigger was a nigger, and the Mississippi way of life was under assault," Chalmers writes. ${ }^{75}$

That opposition to violence was based on strategic rather than moral grounds points to collective and widely shared beliefs on the necessity to maintain racial hierarchy. Beyond extremist organizations like the Klan, at least implicit in these beliefs were the myths of superiority and inferiority of races, repeated over and over again in popular narratives. But for those willing to engage in violence, these myths also provided an ideological justification for violence that was mostly but not solely directed toward African Americans. According to Chalmers, even respectable Mississippians were not surprised that someone named Schwerner who came from New York "to stir up things" was murdered. "What else could be expected?" they asked. ${ }^{76}$ It seems that other patterns of resistance were exhausted to an extent that hardline segregationists drifted toward militant and violent options. But Chalmers argues that like the force used by Eugene "Bull" Connor of Birmingham and Jim Clark of Selma, Klan violence helped to unravel rather than advance the segregationist cause. ${ }^{77}$

In addition to violence, splintering and disputes characterized Klan organizations in the 1960s. Wally Butterworth exemplified these tendencies, as he worked with both the Georgia-based National Knights led by James Venable and Robert Shelton's UKA but parted ways with both organizations. While leaders like Venable and Shelton wielded some influence in terms

73 For Freedom Summer documents and testimonies, see Edmonds, ed., Risking Everything.

74 Chalmers, Hooded Americanism, 392.

75 Ibid.

76 Ibid.

77 Ibid., 373, 387. 
of strategy and ideology in their respective organizations, co-operation remained scant and ineffective. Numerous disputes also highlight the aim of each organization to claim the mantle of authenticity as the "true Klan."78 To promote Klan message, Venable and Butterworth set up a number of front organizations. Among these were the Defensive Legion of Registered Americans and its subsidiary the Christian Voters \& Buyers League. Through these fronts, Venable and Butterworth organized a highly racist and anti-Semitic propaganda campaign that was based on Butterworths phonograph records and broadcasts and other printed publications. ${ }^{79}$

Similar front organizations were set up to reach those who were sympathetic to the cause but could not afford to be publicly associated with a Klan organization. Such was the case with the Mississippi White Knights' front organization WASP, Inc., short for White Anglo-Saxon Protestant. WASP claimed to be "a nonprofit organization dedicated to the ChristianAmerican heritage." ${ }^{\circ 0}$ Like the Defensive Legion, WASP produced and distributed provocative and racist material to inflame a white backlash in the name of white supremacy. In an attempted move from rhetoric to substantive action, the Committee of One Million Caucasians To March on Congress, yet another front established by Venable and Butterworth, aimed to organize "a mass descent on the Nation's Capital on July 4, 1964." The aim, they declared, was to "wrest control of the U.S. government from the communist hands of foreign Asiatic Jews and African Negroes." 81

The march was by all accounts a failure, due to disagreements between Venable and Butterworth and the intrusion of George Lincoln Rockwell's American Nazi Party in the march. In the end, instead of one million white people, only 20 followers of Venable made the trip to Washington. ${ }^{82}$ Although organizations like Venable's National Knights could provide propaganda, they had serious troubles in organizing. The reliance on cultural signifiers to demonize enemies might have incited short-term passions among listeners and readers but attempts to organize mass demonstrations and to show power in numbers often fell flat. Above all, front organizations, propaganda campaigns, and marches can be seen as struggles in a debate of the identity of the U.S. as a nation, a debate in which the Klan's idea

\footnotetext{
78 U.S. House of Representatives, The Present Day Ku Klux Klan Movement, 17.

79 Ibid., 54.

80 Ibid., 47.

81 Cited in U.S. House of Representatives, The Present Day Ku Klux Klan Movement, 54.

82 Ibid.; FBI, Klan Organizations, 54-55.
} 
of the U.S. as a white nation was on the margins. ${ }^{83}$ It was the Civil Rights Movement that was winning the debate by engaging in both structural and moral arguments about the roots, nature, and evils of racism. ${ }^{84}$ Indeed, as Eric Foner has noted, the Civil Rights Movement helped to form a new civic understanding of Americanism. ${ }^{85}$ The Klan, in stark contrast, debated mainly in cultural arguments relying on racist stereotypes and myths which might have justified or sanctified the cause for Klansmen. For the majority of the population, such arguments were too extreme. But unlike myths, race relations did not fit into a tidy narrative.

\section{Conclusion}

The legal structure that upheld segregation was more vulnerable than other safeguards of racial order. The Civil Rights Act was passed in 1964 and the Voting Rights Act in 1965, but other difficult tasks laid ahead for the civil rights workers. As seen in the transition from slavery to Jim Crow, it is difficult to uproot sociopolitical hierarchies, for they tend to transmute into subtler forms, invade new arenas, only to emerge again in social structures. Though the Klan was in the fringes of society, belief in racist stereotypes and support for certain hierarchies was more common. In this function, myths were common cultural grounding to successive resistance efforts by hardline segregationists, giving acts a sense of transcendence that went beyond contemporary issues. Various narratives and practices ranging from "black beasts to Jew-communism," Anglo-Saxon superiority to Klan heroism during Reconstruction, Christian mythos to "Klankraft," all had a common component in Klan thought and action: to reduce all other social struggles such as a class issues into racial antagonisms. In this mindset,

83 David Cunningham has noted how Klan leaders deployed "whiteness" as the central category for a shared identity, elevating "racial identity as the political, moral, and social center of American citizenship." See Cunningham, Klansville, U.S.A., 139-140.

84 Charles Payne has argued that in post-Brown atmosphere, however, the nation came to understand race in non-structural and non-systemic terms, essentially detached from systematic forms of oppression and leading many to believe that Civil Rights laws would solve racial problems in the nation. Charles M. Payne, "The Whole United States Is Southern!": Brown v. Board and the Mystification of Race," The Journal of American History 91, 1 (June 2004): 83-91. On religious arguments both for and against civil rights, see Jane Dailey, "Sex, Segregation, and the Sacred after Brown," The Journal of American History 91, 1 (June 2004): 119-144. On civil rights and civic nationalism, see Gary Gerstle, American Crucible: Race and Nation in the Twentieth Century (Princeton, NJ: Princeton University Press, 2017), 270-286. Eric Foner, The Story of American Freedom (New York: W.W. Norton, 1998), 282. 
certainty of evil and malign intents of Jews was matched by the certainty of their power, control, and influence. Similarly, racist stereotypes of black people and the myth of black inferiority were fashioned into a claim that "Jew-communism" was the real "money and brains" behind the Civil Rights Movement.

At the core of Klan ideology was racism. It gave all other ideological elements their rationale, justification, and function. The Klan, in its aim to maintain white supremacy, reasoned the urgency and necessity of various acts that included terror and violence. Racist myths and stereotypes provided emotional coherence to narratives that responded to Klan base that felt their way of life threatened. For the Klan, myths, stereotypes, and conspiracies functioned together as an ideological lighting rod that directed what otherwise might have been commonalities like class interests toward difference based on racial distinctions. As such, Klan attempts to mythologize race was to maintain hierarchies and to naturalize those differences. 